\title{
Molecular mechanisms of neuropathological changes in Alzheimer's disease: a review
}

\author{
Omar Šerý1, Jana Povová2, Ivan Mišek³, Lukáš Pešák', Vladimír Janout ${ }^{2}$ \\ 1Laboratory of Neurobiology and Molecular Psychiatry, Department of Biochemistry, Faculty of Science, Masaryk University, Brno, \\ Czech Republic, ${ }^{2}$ Department of Epidemiology and Public Health, Faculty of Medicine, University of Ostrava, Czech Republic, \\ 3Department of Animal Embryology, Cell and Tissue Differentiation, Institute of Animal Physiology and Genetics, Academy of Sciences \\ of the Czech Republic, Brno, Czech Republic
}

\begin{abstract}
More than 100 years after description of Alzheimer's disease (AD), two major pathological processes observed already by Alois Alzheimer, remain as the main explanation of the pathogenesis of Alzheimer's disease. Important molecular interactions leading to $A D$ neuropathology were described in amyloid cascade and in tau protein function. No clinical trials with novel therapies based on amyloid cascade and tau protein hypotheses have been successful. The main aim of recent research is focused on the question what is primary mechanism leading to the molecular development of $A D$ pathology. Promising explanation of triggering mechanism can be seen in vascular pathology that have direct influence on the development of pathological processes typical for Alzheimer disease. Novel insight into a number of cellular signaling mechanisms, as well as mitochondrial function in Alzheimer disease could also bring explanations of initial processes leading to the development of this pathology.
\end{abstract}

Key words: amyloid precursor protein, tau protein, apolipoprotein E, secretase, mitochondria, vascular.

\section{Introduction}

Alzheimer's disease (AD) was described as "presenile dementia" first in 1906 by German psychiatrist Alois Alzheimer, colleague of Emil Kraepelin. In 1901, Alzheimer observed a patient named Auguste D. with a progressive loss of cognitive functions (comprehension and memory, unpredictable behaviour etc.). Auguste D. died in April 1906. Alzheimer analysed her brain postmortem using histological methods and wrote in the description "Numerous small miliary foci are found in the superior layers. They are determined by storage of peculiar material in the cortex" [39]. Alzheimer continued: "all in all we have to face a peculiar disease process. Such peculiar disease processes have been verified recently in considerable numbers". "Miliar foci, which are caused by deposition of a peculiar substance in the cortex" are recognised today as senile plaques and "very peculiar changes in the neurofibrils" are recognised today as helical tangles. Emil Kraepelin introduced the eponym "Alzheimer's disease" for "presenile dementia" [39]. More than 100 years after describing of Alzheimer's disease, two major pathological processes (amyloid beta and tau protein deposition) observed already by Alois 
Alzheimer remain the main explanation of pathogenesis of Alzheimer's disease even though some other very important molecular, genetic and epidemiological hypotheses were expressed [53]. The main problem of the explanation of pathophysiology of Alzheimer's disease still could be seen in the inability to identify key mechanisms that release pathologies observed in $A D$.

\section{Amyloid cascade hypothesis}

The human amyloid precursor protein (APP) was first identified in 1987 by several laboratories [20,64,57]. The APP gene was then mapped to chromosome 21 [58]. It has been determined that the APP gene contains 19 exons and spans more than $170 \mathrm{~kb}$ [74]. APP has several isoforms generated by alternative splicing of exons 1-13, 13a, and 14-18. The predominant transcripts are APP695 (exons 1-6, 9-18, not 13a), APP751 (exons 1-7, 9-18, not 13a), and APP770 (exons 1-18, not 13a).

Amyloid precursor protein is type I transmembrane protein. Amyloid precursor protein is synthesized in the endoplasmic reticulum and then transported through the Golgi apparatus to the trans-Golgi network (TGN) where it is stored to its higher concentration at steady state [66].

Over 32 different APP missense mutations have been identified in 85 families [6]. Mutations within APP account for $10 \%$ to $15 \%$ of early-onset familial AD. Most cases containing APP mutations have an age of onset in the mid-40s and 50s [23]. It was observed that patients with Down syndrome (trisomy 21) develop amyloid deposits. Amyloid deposits cause the neuropathological features of $A D$ patients when they are in their 40s. Three morphological subtypes of amyloid deposit are observed in the brain of $A D$ patients: a) diffuse deposits, in which $A \beta$ peptide is not aggregated into the amyloid, b) primitive deposits, in which the $A \beta$ peptide is aggregated into the amyloid and associated with dystrophic neuritis and helical filaments, and c) classic deposit, in which $A \beta$ is highly aggregated to form a central amyloid "core" surrounded by a "ring" of dystrophic neuritis [3]. Armstrong [3] found a larger average cluster size of the diffuse deposit in patients with a familial form of Alzheimer's disease in comparison with patients with sporadic Alzheimer's disease. Presented evidence suggests that postmenopausal oestrogen replacement therapy may prevent or delay the onset of $A D$ [67]. It has been determined that the beneficial effect of oestrogen is mediated by accelerated trafficking of beta APP through the trans-Golgi network (TGN), which precludes maximal beta-amyloid production [21].

Amyloid precursor protein can be processed at different cleavage sites by different proteases to few peptides with biological functions. Amyloid precursor protein undergoes posttranslational proteolytic processing by $\alpha$-, $\beta$-, and $\gamma$-secretases. $\alpha$-secretase generates soluble amyloid protein, while $\beta$ - and $\gamma$-secretases generate APP components with amyloidogenic features.

\section{$\alpha$-secretase}

Amyloid precursor protein processing by $\alpha$-secretase precludes the production of small peptides called $\beta$-amyloid. Amyloid precursor protein is delivered to the plasma membrane by the cytoskeletal system where it is subjected to proteolytic processing by $\alpha$-secretase. A soluble molecule named SAPP $\alpha$ is released after this cleavage. SAPP $\alpha$ has an important role in neuronal plasticity/survival and it is protective against excitotoxicity. SAPP $\alpha$ also regulates neural stem cell proliferation and is important for early CNS development [48].

$\alpha$-secretase is a zinc metalloproteinase that is also type-I transmembrane protein. The family of proteins with $\alpha$-secretase activity includes ADAM9, ADAM10 and ADAM17. Constitutive $\alpha$-secretase is ADAM10 [33]. Disruption of ADAM10 activity has been shown to decrease the level of soluble non-amyloidogenic APP, suggesting that maintaining ADAM10 activity may play a protective role in Alzheimer's disease for processing of APP via the $\alpha$-secretase pathway. Biologically important substrates of ADAM10 include the epidermal growth factor (EGF), betacellulin, Notch, and amyloid precursor protein (APP) [40]. Two potentially pathogenic mutations with incomplete penetrance for late-onset familial AD in the ADAM10 gene were described and it has been found that ADAM10 has $\alpha$-secretase activity that mediates the effect of cholesterol (influence of apolipoprotein E) on APP metabolism [30,32]. Treatment of various peripheral and neural human cell lines with either a cholesterol-extracting agent or an HMGCoA reductase (HMGCR) inhibitor resulted in a drastic increase of secreted alpha-secretase-cleaved soluble APP peptides. It has been demonstrated that cholesterol reduction promotes the non-amyloidogenic alpha-secretase pathway and the formation of neuroprotective alpha-secretase cleaved soluble APP by several mechanisms [32]. 


\section{$\beta$-secretase}

Absence of the $\alpha$-secretase cleavage leads to APP molecules internalization into endocytic compartments where they are subjected to cleavage by $\beta$ - and $\gamma$-secretases to generate $A \beta$. Amyloid precursor protein $\beta$-secretase 1 (BACE1) was identified and described $[70,73]$. $\beta$-secretase 1 is $\beta$-secretase involved in APP metabolism. $\beta$-secretase 1 is a membrane-bound aspartyl protease with a characteristic type I transmembrane domain near C-terminus. The BACE gene is located on chromosome 11 and consists of nine exons coding for a protein of 501 amino acids [64]. $\beta$-secretase 1 pre-mRNA can undergo alternative splicing in exons 3 and 4, which results in the production of four alternative variants with 501, 476, 457, and 432 amino acids. The shorter splice variants have little cleavage activity on APP substrate compared to the 501 amino acid protein [41]. Precursor of BACE1, named pro-BACE1 is modified by glycosylation, phosphorylation and then cleaved by a furin-like endoprotease to produce mature BACE1. After synthesis in the endoplasmic reticulum, BACE1 is transported through the secretory route to the plasma membrane from where it is re-internalized into endosomal compartments [55]. $\beta$-secretase 1 requires acidic environment for optimal activity. This optimal environment is provided by endosomes.

$\beta$-secretase expression increases with age [18], and is particularly elevated in the brain cortex of $A D$ patients [24]. Several mechanisms have been proposed to explain this increase [26]. A defect in BACE trafficking due to caspase degradation of the GGA that controls BACE intracellular sorting, or a loss of control of BACE mRNA translation have been proposed as mechanisms to explain age-dependent increase of BACE expression. Oxidative stress and other conditions such as hypoxia, ischaemia, and energy deprivation have also been found to elevate BACE expression in cellular models [22]. $\beta$-secretase 1 is still recognised as the drug target for the treatment of Alzheimer's disease even though many important proteins are additional BACE1 substrates, e.g. low/density lipoprotein receptor/related protein, $\mathrm{P} /$ selectin glycoprotein ligand/1, neuregulin (Nrg1-type III $\beta 1$, and Nrg3) and the $\beta 2$ subunit of voltage-gated sodium channel $\left(\mathrm{Na}_{v} 1, \beta_{2}\right)$, some of which play an important role in the development and normal function of the brain [16]. $\beta$-secretase 2 (BACE2) is another $\beta$-secretase that cleaves APP near the $\alpha$-secretase site more efficiently than BACE1 and this suggest that BACE1 is primary $\beta$-secretase.
After APP cleavage by BACE1, ectodomain of APP is released as a soluble peptide named SAPP $\beta$. Region 1-16 of carboxyl-terminus that lacks SAPP $\beta$ is the difference between SAPP $\alpha$ and SAPP $\beta$. The role of both peptides is dramatically different. SAPP $\beta$ has a function as ligand of death receptor 6 , mediates axonal pruning and neuronal cell death [46].

After $\alpha$ - and $\beta$-cleavage, the carboxyl terminal fragments (CTFs) of APP described as $\alpha$ CFT and $\beta$ CFT remain membrane-associated and will be further cleaved by $\gamma$-secretase. Overproduction of $\beta$ CFT has a cytotoxic effect and causes neuronal degeneration. It could be also done by cytotoxic peptides C31 and Jcasp that arise from cleavage of $\beta$ CFT by $\gamma$-secretase or by caspase, including APP intracellular domain [49].

\section{$\gamma$-secretase}

$\alpha$ CFT is processed by $\gamma$-secretase to $\mathrm{p} 83$ peptide that is rapidly degraded and its function was not described. $\beta C F T$ is cleaved by $\gamma$-secretase to $A \beta 40$ and $A \beta 42$. Recently, other sites cleavage by $\gamma$-secretase have been described - $\zeta$-site $(A \beta 46)$ and $\varepsilon$-site (A $\beta 49)$. $\alpha C F T$ is then processed sequentially in $\varepsilon$-site, $\zeta$-site and finally in $\gamma$-site [75].

$\gamma$-secretase is a big complex composed from a few components, mainly from four proteins: presenilin (PS, PS1 or PS2), nicastrin, anterior pharynx-defective-1 (APH-1) and presenilin enhancer-2 (PEN-2). $\gamma$-secretase complex is located in endoplasmic reticulum, Golgi complex and trans-Golgi network, endocytic and intermediate compartments [61].

In human, two homologues of presenilin were described - presenilin 1 and presenilin 2. Mutations in PS1 (and also PS2) were described in the familial form of AD. More than 1000 point mutations in the presenilins are responsible for most of the familial forms of AD [47].

\section{Amyloid precursor protein trafficking}

Amyloid precursor protein is biosynthesized in endoplasmic reticulum and anterogradely transported to the Golgi apparatus and then to the trans-Golgi network in distinct transport vesicles by conventional kinesin. In the trans-Golgi network APP undergoes various posttranslational modifications (phosphorylations, tyrosine sulfations and $N$ - and $O$-glycosylations). Recently, calsyntenin-1 has been shown to be co-transported with APP along axons [69]. Calsyntenin-1 brain cellular level is reduced in persons with Alzheimer's disease and 
the extent of calsyntenin-1 reduction correlates with increased $A \beta$ levels. GTPase activity of Rab3, a small G-protein of the Rab family that is involved in the late steps of exocytosis, is required for APP transport vesicles [65].

After insertion of APP at the plasma membrane it undergoes rapid clathrin-mediated endocytosis. C-terminal of APP with four amino acid sequence, YENPY, is the major signal for clathrin-mediated APP endocytosis [50]. Many intracellular adaptors bind to this C-terminal part of APP, for example Fe65, Mint proteins, Dab1 or JIP [11]. Lipoprotein receptor-related protein (LRP1) and apolipoprotein E receptor 2 are able to interact directly with APP. Depending on the linker protein involved, apolipoprotein E receptor 2 and APP are connected intracellularly via Dab1 (disabled family member), Mint1 or Fe65 adaptors or extracellularly by F-spondin [11]. There are alternative ways of APP after internalization. Amyloid precursor protein can be transported rapidly and directly from the cell surface to lysosomes [36]. Amyloid precursor protein can be also degraded in proteasome [9]. Amyloid precursor protein can be transported from endosomes to Golgi apparatus and/or TGN from where it could be distributed back to plasma membrane.

\section{$A \beta$ function}

It has been shown that the extracellular domain of APP is especially important for promoting synapse formation. Trans-synaptic interactions between preand postsynaptic APP contribute to the adhesion of synapses [72]. It was found that APP knock-out and also BACE1 knock-out mice show impaired memory [31]. It suggests a necessary role of $A \beta$ in learning and memory. Recently, it was found that a low level of $A \beta$ increases hippocampal long-term potentiation and enhances memory, indicating a novel positive, modulatory role on neurotransmission and memory [54]. Picomolar A $\beta$ is present in both the cerebrospinal fluid and plasma of healthy individuals throughout life. It has been shown that picomolar concentrations of both $A \beta 42$ monomers and oligomers cause a marked increase in long-term potentiation, whereas high nanomolar concentrations lead to the well-established reduction of potentiation in the hippocampus [54].

There are two main toxic species of $A \beta-A \beta 40$ and $A \beta 42$. The increase in the ratio of $A \beta 42 / A \beta 40$ is typical of $A D$ patients [62]. Majority of $A \beta$ peptides is secreted from the neurons as $A \beta 40$. A smaller fraction of $A \beta 42$ is cleaved to produce $A \beta 42$ that is the main amyloid peptide that is responsible for the production of amyloid fibrils in AD patients. A $\beta 42$ self-associates to dimmers, soluble oligomers and to insoluble aggregates of fibrils. Extracellular $A \beta$ can be internalized by cells for intracellular degradation, e.g. by insulin-degrading enzyme and neprilysin. Presented data imply a mechanism for the formation of $A \beta$ amyloid plaques in which initially soluble and extracellular $A \beta$ peptide becomes internalized and sorted into multivesicular bodies [17]. Upon spontaneous nucleation or in the presence of suitable fibril seeds, fibrils grow out, disturb the ordered multivesicular bodies function and penetrate the vesicular membrane. Ultimately cells die and all intracellular structures, including all intracellular amyloid species, become released into the extracellular space [17]. The cytotoxic effect of $A \beta$ could be achieved also by the above described C31 and Jcasp peptides released during $\beta$ CFT cleavage.

There have been more than 30 investigations assessing plasma amyloid beta $A \beta 40$ and $A \beta 42$ as a diagnostic or as a biological risk factor. $A \beta 42$ and $A \beta 42$ / $A \beta 40$ ratio levels were elevated in unaffected familial $A D$ mutation carriers compared with unaffected individuals with familial AD without mutations [56]. However, $A \beta 42$ levels were lower in mutation carriers with incipient $A D$ characterized as having a clinical dementia rating $(C D R)=0.5$ [25], supporting the hypothesis that $A \beta 42$ decreases prior to overt disease.

Recently, the transfer of $A \beta$ between neurons has been described. This transfer is dependent on the synaptic connection between neurons [44]. Previously, the degeneration of entorhinal cortex in the initial stage of $A D$ and subsequent degeneration of connected areas was described. The exogenous intracerebral injection of $A \beta$ aggregates taken from brain extracts of $A D$ patients induced cerebral amyloidogenesis that progresses from the injection site in APP transgenic mice. Newly described transfer of $A \beta$ between neurons could explain spreading the neurodegenerative pathology to anatomically connected brain areas [44].

\section{Tau protein (microtubule-associated protein tau, MAPT)}

The human gene for tau protein (MAPT gene) is located on chromosome 17 [45]. It contains 15 exons. Exons 2, 3 and 10 are alternatively spliced resulting in six isoforms. There are 79 potential serine and threonine phosphate acceptor residues in the longest iso- 
form of tau. Tau has more than 30 phosphorylated sites. Normal tau protein stabilizes microtubules in the cytoskeleton of neurons, promote neurite outgrowth, membrane interactions, facilitate enzyme anchoring and facilitate axonal transport of organelles to nerve terminals [27]. The phosphorylation of tau protein regulates microtubule binding and assembly [71]. It has been demonstrated that in solution normal tau associated with the hyperphosphorylated tau protein to form large tangles of filaments [1]. In AD, tau protein is hyperphosphorylated then it accumulates in neurons and forms paired helical filaments. Tau protein loses its capability to bind with microtubules and it leads to neurodegeneration. Astrocytes are essential for the $A \beta$-induced tau phosphorylation observed in primary neurons [19].

Causal factors affecting phosphorylation of tau are not fully understood but according to observation, multiple factors in this process are expected.

Abnormal binding of hyperphosphorylated tau protein on microtubules typical of AD patients causes instability of microtubules and lead to abnormal axonal transport that is dependent on microtubules. $A \beta$ and mitochondria are transported along microtubules by molecular motors. Inhibition of axonal transport leads to accumulation of APP in cell body. It was found that impaired axonal transport of organelles including mitochondria causes oxidative stress [38].

In the tau gene no mutation related to AD was found. There was reported the association between the $\mathrm{H} 1 \mathrm{C}$ subhaplotype of the MAPT gene and the risk of Alzheimer's disease in 360 autopsy-confirmed cases with ages at death over 65 years of age and 252 controls [42].

It was demonstrated that the MAPT gene rs242557 polymorphism that is part of the H1c subhaplotype, results in increased MAPT gene expression [34]. The authors also provided evidence that the $\mathrm{H} 1 / \mathrm{H} 2$ MAPT haplotype interacts with functional SNPs in the GSK3B gene to affect the risk of Alzheimer's disease.

The relationship between tau protein and mitochondria was recently described. Tau protein was found on mitochondrial membranes. It is increasingly accepted that the trafficking to, and density of, mitochondria at subcellular locations with the energy and $\mathrm{Ca}^{2+}$-buffering requirements, including synapses, is important for correct neuronal function [37]. The distribution of mitochondria in axons and dendrites correlates closely with the predicted energy usage of these compartments. Mitochondria undergo rapid trafficking in axons and dendrites. Synaptic activity modulates mitochondrial motility and morphology and controls mitochondrial distribution in dendrites and their recruitment to the base of dendritic spines [35]. In the experiment conducted on neurons transfected with tau protein, mitochondria disappeared from the neurites and became concentrated in the cell body [63]. Preferential inhibition of plus-end-directed transport (outside the cell centre) of mitochondria and other organelles by kinesin molecular motors was observed as a result of tau protein level elevation. Minus-end-directed transport (inside the cell centre) by a dynein-like motor then becomes dominant [63].

\section{Apolipoprotein $\mathrm{E}$}

Apolipoprotein $\mathrm{E}$ is a cholesterol transport protein. It can be found mainly as a component of lipoprotein complexes along with other apolipoproteins and proteins in plasma and CSF. Three alleles ( $\varepsilon 2-$ Cys112/ Cys158, $\varepsilon 3$ - Cys112/Arg158 and $\varepsilon 4$ - Arg112/Arg158) were described in humans, according to combinations in two polymorphic sites. Amino acid differences at these positions are crucial as they alter the charge and structural properties of the protein.

The ApoE gene has been associated with both familial late-onset and sporadic late-onset $A D$ in numerous studies. To date only ApoE4 has been firmly identified as a genetic risk factor, although segregation analyses conducted in families of patients with LOAD support the presence of additional genetic variants [13]. With a population attributable risk that is estimated at 20$50 \%$, the ApoE4 allele increases the risk of cognitive impairment, LOAD, and age-of onset of cognitive impairment in a dose-dependent fashion: $1 \varepsilon 4$ allele is associated with a 2- to 3-fold increased risk, having 2 copies is associated with a 5- to 10-fold increase. Similar effect sizes have been observed for progression of cognitive impairment to dementia. Individuals carrying ApoE4 allele have higher total and LDL cholesterol [60].

High cholesterol levels have been linked to overproduction of $A \beta$. One of the physiological functions of $A \beta$ has been suggested to control cholesterol transport. Individuals of 50 years and older who were prescribed statins had a substantially lowered risk of developing dementia, independent of the presence or absence of untreated hyperlipidaemia, or exposure to non-statin LLAs [28]. Cholesterol greatly reduced the levels of SAPP $\alpha$. ADAM10 is unable to cleave APP in a cholesterol-rich environment [32]. Changes in cellular cholesterol levels in Alzheimer's disease could contribute 
to neuronal degeneration by decreasing the production of SAPP $\alpha$ [7].

\section{Possible mechanisms triggering Alzheimer's disease pathology}

Vascular and mitochondrial hypotheses of pathogenesis of AD were also stated. Several vascular risk factors e.g. diabetes mellitus, hypertension, atherosclerosis, hypercholesterolemia, metabolic syndrome and obesity, have been found to be associated with Alzheimer's disease [51,52]. The apolipoprotein E genotype with the link to dynamics of cholesterol transport is also implicated as a vascular risk factor in influencing $A D$ [29]. AD patients often exhibit various cerebrovascular pathologies including cerebral microbleeding $[14,15,43]$ and cerebral microinfarcts. Microinfarcts are common in patients with vascular dementia (weighted average 62\%), Alzheimer's disease (43\%), and demented patients with both Alzheimer-type and cerebrovascular pathology (33\%) compared with nondemented older individuals (24\%) [8]. Cerebral hypoperfusion may initiate and/or accelerate the neurodegeneration cascade causing amyloid deposition, synaptic and neural dysfunction and lead to cognitive impairment $[29,51,52]$. A $\beta$ deposition into the capillary wall is strongly associated with the ApoE4 allele as a risk factor [4]. Oxidative stress that can be influenced by hypoxia and also by mitochondrial dysfunction is associated with AD pathogenesis.

Mitochondrial dysfunction relationship with $A D$ could be explained by abnormalities in mitochondrial metabolism, biogenesis, axonal transport, fusion and fission processes and by autophagy $[10,12]$. Functional mitochondria are supplied to the synaptic terminals by anterograde transport by microtubule associated protein kinesin and dysfunctional mitochondria are transported back to cell soma by dynein [59]. Tau protein has been implicated in abnormal mitochondrial trafficking when hyperphosphorylation of Tau protein negatively affects the transport of mitochondria to synapses and back. The lack of ATP energy in synaptic terminals affects synaptic function and it leads to synaptic damage. The accumulation of transmembrane arrested APP block protein translocation, disrupts mitochondrial function, and impair brain energy metabolism [5]. It has been shown that the interaction between $\mathrm{A} \beta$ and $\mathrm{NH}_{2}$-tau fragment inhibit the mitochondrial adenine nucleotide translocator-1 (ANT-1) [2]. ANT-1 has a function in export of mitochondrial ade- nosine triphosphate into the cytosol and has a role in the regulation of the intrinsic apoptosis pathway.

\section{Conclusions}

Alzheimer's disease $(A D)$ is the most common cause of dementia, affecting more than $10 \%$ of people over the age of 65 . Although considerable progress in the understanding of the molecular mechanisms of the pathogenesis of AD has been made, many aspects, especially key mechanisms that release pathologies, remain controversial. Promising research is focused on the research of hypoxia and oxidative stress caused by different mechanisms, e.g. by vascular and mitochondrial pathologies. $A \beta$ deposition in different cell compartments and in extracellular areas and its pathophysiological role remains to be explained in relationship to other molecular mechanisms. It could be concluded that up to date we know many mechanisms that could affect set up and progress of AD pathogenesis. It seems like $A D$ is not only one or two types of diseases but it could be a group of diseases with similar APP and Tau pathologies that are triggered by different mechanisms. Genetic disposition to AD would play an important role in the mechanisms of Alzheimer's disease initiations. Thus, we could expect a group of diseases specified as Alzheimer's disease when the interplay of environmental and genetic factors would be responsible for the type of initiation of AD pathogenesis.

\section{Acknowledgement}

This work has been supported by the internal grant agency of the Ministry of Health of the Czech Republic (IGA MZCR) No. NT/11152-6.

\section{Reference}

1. Alonso AC, Grundke-lqbal I, Iqbal K. Alzheimer's disease hyperphosphorylated tau sequesters normal tau into tangles of filaments and disassembles microtubules. Nat Med 1996; 2: 783-787.

2. Amadoro G, Corsetti V, Atlante A, Florenzano F, Capsoni S, Bussani R, Mercanti D, Calissano P. Interaction between $\mathrm{NH}(2)$-tau fragment and $A \beta$ in Alzheimer's disease mitochondria contributes to the synaptic deterioration. Neurobiol Aging 2012; 33: 833.e1-25; doi: 10.1016/j.neurobiolaging.2011.08.001

3. Armstrong RA. Spatial patterns of $\beta$-amyloid $(A \beta)$ deposits in familial and sporadic Alzheimer's disease. Folia Neuropathol 2011; 49: 153-161.

4. Attems J, Yamaguchi H, Saido TC, Thal DR. Capillary CAA and perivascular $A \beta$-deposition: two distinct features of Alzheimer's disease pathology. J Neurol Sci 2010; 299: 155-162. 
5. Baloyannis SJ. Mitochondria are related to synaptic pathology in Alzheimer's disease. Int J Alzheimers Dis 2011; doi: 10.4061/2011/ 305395, in press.

6. Bekris LM, Yu CE, Bird TD, Tsuang DW. Genetics of Alzheimer disease. J Geriatr Psychiatry Neurol 2010; 23: 213-227.

7. Bodovitz S, Klein WL Cholesterol modulates alpha-secretase cleavage of amyloid precursor protein. J Biol Chem 1996; 271: 4436-4440.

8. Brundel M, de Bresser J, van Dillen JJ, Kappelle LJ, Biessels GJ. Cerebral microinfarcts: a systematic review of neuropathological studies. J Cereb Blood Flow Metab 2012; 32: 425-436.

9. Buoso E, Lanni C, Schettini G, Govoni S, Racchi M. beta-Amyloid precursor protein metabolism: focus on the functions and degradation of its intracellular domain. Pharmacol Res 2010; 62: 308-317.

10. Carvalho C, Cardoso S, Correia SC, Santos RX, Santos MS, Baldeiras I, Oliveira CR, Moreira PI. Metabolic alterations induced by sucrose intake and Alzheimer's disease promote similar brain mitochondrial abnormalities. Diabetes 2012; 61: 1234-1242.

11. Claeysen S, Cochet M, Donneger R, Dumuis A, Bockaert J, Giannoni P. Alzheimer culprits: cellular crossroads and interplay. Cell Signal 2012; 24: 1831-1840.

12. Correia SC, Santos RX, Cardoso S, Carvalho C, Candeias E, Duarte AI, Plácido Al, Santos MS, Moreira PI. Alzheimer disease as a vascular disorder: Where do mitochondria fit? Exp Gerontol 2012; 11: 878-886.

13. Daw EW, Payami H, Nemens EJ, Nochlin D, Bird TD, Schellenberg GD, Wijsman EM. The number of trait loci in late-onset Alzheimer disease. Am J Hum Genet 2000; 66: 196-204.

14. De Reuck IL, Cordonnier C, Deramecourt V, Auger F, Durieux N, Bordet R, Maurage CA, Leys D, Pasquier F. Microbleeds in Postmortem Brains of Patients With Alzheimer Disease: A T2*-weighted Gradient-Echo 7.0 T Magnetic Resonance Imaging Study. Alzheimer Dis Assoc Disord 2012; in press.

15. De Reuck JL, Deramecourt V, Cordonnier C, Leys D, Pasquier F, Maurage CA. Cerebrovascular lesions in patients with frontotemporal lobar degeneration: a neuropathological study. Neurodegener Dis 2012; 9: 170-175.

16. Evin G, Barakat A, Masters CL. BACE: Therapeutic target and potential biomarker for Alzheimer's disease. Int J Biochem Cell Biol 2010; 42: 1923-1926.

17. Friedrich RP, Tepper K, Ronicke R, Soom M, Westermann M, Reymann K, Kaether C, Fandrich M. Mechanism of amyloid plaque formation suggests an intracellular basis of Abeta pathogenicity. Proc Natl Acad Sci U S A 2010; 107: 1942-1947.

18. Fukumoto H, Rosene DL, Moss MB, Raju S, Hyman BT, Irizarry MC. Beta-secretase activity increases with aging in human, monkey, and mouse brain. Am J Pathol 2004; 164: 719-725.

19. Garwood CJ, Pooler AM, Atherton J, Hanger DP, Noble W. Astrocytes are important mediators of Abeta-induced neurotoxicity and tau phosphorylation in primary culture. Cell Death Dis 2011; in press; doi: 10.1038/cddis.2011.50.

20. Goldgaber D, Lerman MI, McBride OW, Saffiotti U, Gajdusek DC Characterization and chromosomal localization of a cDNA encoding brain amyloid of Alzheimer's disease. Science 1987; 235: 877-880.

21. Greenfield JP, Leung LW, Cai D, Kaasik K, Gross RS, RodriguezBoulan E, Greengard P, Xu H. Estrogen lowers Alzheimer beta-amyloid generation by stimulating trans-Golgi network vesicle biogenesis. J Biol Chem 2002; 277: 12128-12136.
22. Guglielmotto M, Aragno M, Autelli R, Giliberto L, Novo E, Colombatto S, Danni O, Parola M, Smith MA, Perry G, Tamagno E, Tabaton $M$. The up-regulation of BACE1 mediated by hypoxia and ischemic injury: role of oxidative stress and HIFlalpha. J Neurochem 2009; 108: 1045-1056

23. Hardy J. Genetic dissection of primary neurodegenerative diseases. Biochem Soc Symp 2001; 67: 51-57.

24. Holsinger RM, McLean CA, Beyreuther K, Masters CL, Evin G. Increased expression of the amyloid precursor beta-secretase in Alzheimer's disease. Ann Neurol 2002; 51: 783-786.

25. Hughes CP, Berg L, Danziger WL, Coben LA, Martin RL. A new clinical scale for the staging of dementia. Br J Psychiatry 1982; 140: 566-572.

26. Hunt CE, Turner AJ. Cell biology, regulation and inhibition of betasecretase (BACE-1). FEBS J 2009; 276: 1845-1859.

27. Iqbal K, Liu F, Gong CX, Grundke-Iqbal I. Tau in Alzheimer disease and related tauopathies. Curr Alzheimer Res 2010; 7: 656-664.

28. Jick H, Zornberg GL, Jick SS, Seshadri S, Drachman DA. Statins and the risk of dementia. Lancet 2000; 356: 1627-1631.

29. Kalaria RN, Akinyemi R, Ihara M. Does vascular pathology contribute to Alzheimer changes? J Neurol Sci 2012; 322: 141-147.

30. Kim M, Suh J, Romano D, Truong MH, Mullin K, Hooli B, Norton D, Tesco G, Elliott K, Wagner SL, Moir RD, Becker KD, Tanzi RE. Potential late-onset Alzheimer's disease-associated mutations in the ADAM10 gene attenuate \{alpha\}-secretase activity. Hum Mol Genet 2009; 18: 3987-3996.

31. Kobayashi D, Zeller M, Cole T, Buttini M, McConlogue L, Sinha S, Freedman S, Morris RG, Chen KS. BACE1 gene deletion: impact on behavioral function in a model of Alzheimer's disease. Neurobiol Aging 2008; 29: 861-873.

32. Kojro E, Gimpl G, Lammich S, Marz W, Fahrenholz F. Low cholesterol stimulates the nonamyloidogenic pathway by its effect on the alphasecretase ADAM 10. Proc Natl Acad Sci U S A 2001; 98: 5815-5820.

33. Kuhn PH, Wang H, Dislich B, Colombo A, Zeitschel U, Ellwart JW, Kremmer E, Rossner S, Lichtenthaler SF. ADAM10 is the physiologically relevant, constitutive alpha-secretase of the amyloid precursor protein in primary neurons. EMBO J 2010; 29: 3020-3032.

34. Kwok JB, Loy CT, Hamilton G, Lau E, Hallupp M, Williams J, Owen MJ, Broe GA, Tang N, Lam L, Powell JF, Lovestone S, Schofield PR. Glycogen synthase kinase-3beta and tau genes interact in Alzheimer's disease. Ann Neurol 2008; 64: 446-454.

35. Li Z, Okamoto K, Hayashi Y, Sheng M. The importance of dendritic mitochondria in the morphogenesis and plasticity of spines and synapses. Cell 2004; 119: 873-887.

36. Lorenzen A, Samosh J, Vandewark K, Anborgh PH, Seah C, Magalhaes AC, Cregan SP, Ferguson SS, Pasternak SH. Rapid and direct transport of cell surface APP to the lysosome defines a novel selective pathway. Mol Brain 2010; 3: 11.

37. MacAskill AF, Atkin TA, Kittler JT. Mitochondrial trafficking and the provision of energy and calcium buffering at excitatory synapses. Eur J Neurosci 2010; 32: 231-240.

38. Mandelkow EM, Stamer K, Vogel R, Thies E, Mandelkow E. Clogging of axons by tau, inhibition of axonal traffic and starvation of synapses. Neurobiol Aging 2003; 24: 1079-1085.

39. Maurer K, Volk S, Gerbaldo H. Auguste D and Alzheimer's disease. The Lancet 1997; 349: 1546-1549. 
40. Moss ML, Bomar M, Liu Q, Sage H, Dempsey P, Lenhart PM, Gillispie PA, Stoeck A, Wildeboer D, Bartsch JW, Palmisano R, Zhou P. The ADAM10 prodomain is a specific inhibitor of ADAM10 proteolytic activity and inhibits cellular shedding events. J Biol Chem 2007; 282: 35712-35721.

41. Mowrer KR, Wolfe MS. Promotion of BACE1 mRNA alternative splicing reduces amyloid beta-peptide production. J Biol Chem 2008; 283: 18694-18701.

42. Myers AJ, Kaleem M, Marlowe L, Pittman AM, Lees AJ, Fung HC, Duckworth J, Leung D, Gibson A, Morris CM, de Silva R, Hardy J. The H1c haplotype at the MAPT locus is associated with Alzheimer's disease. Hum Mol Genet 2005; 14: 2399-2404.

43. Nakata-Kudo Y, Mizuno T, Yamada K, Shiga K, Yoshikawa K, Mori S, Nishimura T, Nakajima K, Nakagawa M. Microbleeds in Alzheimer disease are more related to cerebral amyloid angiopathy than cerebrovascular disease. Dement Geriatr Cogn Disord 2006; 22: 8-14.

44. Nath S, Agholme L, Kurudenkandy FR, Granseth B, Marcusson J, Hallbeck M. Spreading of neurodegenerative pathology via neuron-to-neuron transmission of $\beta$-amyloid. J Neurosci 2012; 32: 8767-8777.

45. Neve RL, Harris P, Kosik KS, Kurnit DM, Donlon TA. Identification of cDNA clones for the human microtubule-associated protein tau and chromosomal localization of the genes for tau and microtubuleassociated protein 2. Brain Res 1986; 387: 271-280.

46. Nikolaev A, McLaughlin T, O'Leary DD, Tessier-Lavigne M. APP binds DR6 to trigger axon pruning and neuron death via distinct caspases. Nature 2009; 457: 981-989.

47. Obulesu M, Somashekhar R, Venu R. Genetics of Alzheimer's disease: an insight into presenilins and apolipoprotein $\mathrm{E}$ instigated neurodegeneration. Int J Neurosci 2011; 121: 229-236.

48. Ohsawa I, Takamura C, Morimoto T, Ishiguro M, Kohsaka S. Aminoterminal region of secreted form of amyloid precursor protein stimulates proliferation of neural stem cells. Eur J Neurosci 1999; 11: 1907-1913.

49. Park SA, Shaked GM, Bredesen DE, Koo EH. Mechanism of cytotoxicity mediated by the C31 fragment of the amyloid precursor protein. Biochem Biophys Res Commun 2009; 388: 450-455.

50. Perez RG, Soriano S, Hayes JD, Ostaszewski B, Xia W, Selkoe DJ, Chen X, Stokin GB, Koo EH. Mutagenesis identifies new signals for beta-amyloid precursor protein endocytosis, turnover, and the generation of secreted fragments, including Abeta42. J Biol Chem 1999; 274: 18851-18856.

51. Pluta R, Jabłoński M, Czuczwar SJ. Postischemic dementia with Alzheimer phenotype: selectively vulnerable versus resistant areas of the brain and neurodegeneration versus $\beta$-amyloid peptide. Folia Neuropathol 2012; 50: 101-109.

52. Pluta R, Ułamek M, Jabłoński M. Consideration of the ischaemic basis and treatment of Alzheimer's disease. Folia Neuropathol 2010; 48: 11-26.

53. Povova J, Ambroz P, Bar M, Pavukova V, Sery O, Tomaskova H, Janout $V$. Epidemiological of and risk factors for Alzheimer's disease: A review.Biomed Pap Med Fac Univ Palacky Olomouc Czech Repub 2012; 156: 108-114.

54. Puzzo D, Privitera L, Leznik E, Fa M, Staniszewski A, Palmeri A, Arancio O. Picomolar amyloid-beta positively modulates synaptic plasticity and memory in hippocampus. J Neurosci 2008; 28: 14537 14545.
55. Rajendran L, Honsho M, Zahn TR, Keller P, Geiger KD, Verkade P, Simons K. Alzheimer's disease beta-amyloid peptides are released in association with exosomes. Proc Natl Acad Sci U S A 2006; 103: 11172-11177.

56. Ringman JM, Younkin SG, Pratico D, Seltzer W, Cole GM, Geschwind DH, Rodriguez-Agudelo Y, Schaffer B, Fein J, Sokolow S, Rosario ER, Gylys KH, Varpetian A, Medina LD, Cummings JL. Biochemical markers in persons with preclinical familial Alzheimer disease. Neurology 2008; 71: 85-92.

57. Robakis NK, Ramakrishna N, Wolfe G, Wisniewski HM. Molecular cloning and characterization of a cDNA encoding the cerebrovascular and the neuritic plaque amyloid peptides. Proc Natl Acad Sci U S A 1987; 84: 4190-4194.

58. Robakis NK, Wisniewski HM, Jenkins EC, Devine-Gage EA, Houck GE, Yao XL, Ramakrishna N, Wolfe G, Silverman WP, Brown WT. Chromosome 21q21 sublocalisation of gene encoding beta-amyloid peptide in cerebral vessels and neuritic (senile) plaques of people with Alzheimer disease and Down syndrome. Lancet 1987; 1: 384-385.

59. Sheng ZH, Cai Q. Mitochondrial transport in neurons: impact on synaptic homeostasis and neurodegeneration. Nat Rev Neurosci 2012; 13: 77-93.

60. Sing CF, Davignon J. Role of the apolipoprotein E polymorphism in determining normal plasma lipid and lipoprotein variation. Am J Hum Genet 1985; 37: 268-285.

61. Spasic D, Raemaekers T, Dillen K, Declerck I, Baert V, Serneels L, Fullekrug J, Annaert W. Rerlp competes with APH-1 for binding to nicastrin and regulates gamma-secretase complex assembly in the early secretory pathway. J Cell Biol 2007; 176: 629-640.

62. Spies PE, Slats D, Sjogren JM, Kremer BP, Verhey FR, Rikkert MG, Verbeek MM. The cerebrospinal fluid amyloid beta $42 / 40$ ratio in the differentiation of Alzheimer's disease from non-Alzheimer's dementia. Curr Alzheimer Res 2010; 7: 470-476.

63. Stamer K, Vogel R, Thies E, Mandelkow E, Mandelkow EM. Tau blocks traffic of organelles, neurofilaments, and APP vesicles in neurons and enhances oxidative stress. J Cell Biol 2002; 156: 1051-1063.

64. Stockley JH, O'Neill C. Understanding BACE1: essential protease for amyloid-beta production in Alzheimer's disease. Cell Mol Life Sci 2008; 65: 3265-3289.

65. Szodorai A, Kuan YH, Hunzelmann S, Engel U, Sakane A, Sasaki T, Takai Y, Kirsch J, Müller U, Beyreuther K, Brady S, Morfini G, Kins S. APP anterograde transport requires Rab3A GTPase activity for assembly of the transport vesicle. J Neurosci 2009; 29: 14534-14544.

66. Tan J, Evin G. beta-Site APP-cleaving enzyme 1 trafficking and Alzheimer's disease pathogenesis. J Neurochem 2012; 120: 869-880.

67. Tang MX, Jacobs D, Stern Y, Marder K, Schofield P, Gurland B, Andrews H, Mayeux R. Effect of oestrogen during menopause on risk and age at onset of Alzheimer's disease. Lancet 1996; 348: 429-432.

68. Tanzi RE, Gusella JF, Watkins PC, Bruns GA, St George-Hyslop P, Van Keuren ML, Patterson D, Pagan S, Kurnit DM, Neve RL. Amyloid beta protein gene: CDNA, mRNA distribution, and genetic linkage near the Alzheimer locus. Science 1987; 235: 880-884.

69. Vagnoni A, Perkinton MS, Gray EH, Francis PT, Noble W, Miller CC. Calsyntenin-1 mediates axonal transport of the amyloid precursor protein and regulates $A \beta$ production. Hum Mol Genet 2012; 21: $2845-2854$. 
70. Vassar R, Bennett BD, Babu-Khan S, Kahn S, Mendiaz EA, Denis P, Teplow DB, Ross S, Amarante P, Loeloff R, Luo Y, Fisher S, Fuller J, Edenson S, Lile J, Jarosinski MA, Biere AL, Curran E, Burgess T, Louis JC, Collins F, Treanor J, Rogers G, Citron M. Beta-secretase cleavage of Alzheimer's amyloid precursor protein by the transmembrane aspartic protease BACE. Science 1999; 286: 735-741.

71. Wang IZ, Liu F. Microtubule-associated protein tau in development, degeneration and protection of neurons. Prog Neurobiol 2008; 85: 148-175.

72. Wang Z, Wang B, Yang L, Guo Q, Aithmitti N, Songyang Z, Zheng H. Presynaptic and postsynaptic interaction of the amyloid precursor protein promotes peripheral and central synaptogenesis. J Neurosci 2009; 29: 10788-10801.

73. Yan R, Bienkowski MJ, Shuck ME, Miao H, Tory MC, Pauley AM, Brashier JR, Stratman NC, Mathews WR, Buhl AE, Carter DB, Tomasselli AG, Parodi LA, Heinrikson RL, Gurney ME. Membrane-anchored aspartyl protease with Alzheimer's disease beta-secretase activity. Nature 1999; 402: 533-537.

74. Yoshikai S, Sasaki H, Doh-ura K, Furuya H, Sakaki Y. Genomic organization of the human amyloid beta-protein precursor gene. Gene 1990; 87: 257-263.

75. Zhao G, Cui MZ, Mao G, Dong Y, Tan J, Sun L, Xu X. gamma-Cleavage is dependent on zeta-cleavage during the proteolytic processing of amyloid precursor protein within its transmembrane domain. J Biol Chem 2005; 280: 37689-37697. 